Jurnal Penelitian Pendidikan Geografi Volume 3 No. 4 Oktober 2018

\title{
PENERAPAN MODEL PEMBELAJARAN KOOPERATIF TIPE TALKING STICK UNTUK MENINGKATKAN HASIL BELAJAR SISWA MATA PELAJARAN IPS PADA MATERI POKOK KERAGAMAN BENTUK MUKA BUMI SISWA KELAS VII SMPN SATAP 2 TOWEA
}

(Penelitian Tindakan Kelas Terhadap Siswa Kelas VII SMP Negeri Satap 2 Towea)

\author{
Wa Rusna ${ }^{1}$, La Ode Nursalam ${ }^{2}$ \\ ${ }^{1}$ Alumni Pendidikan Geografi FKIP UHO \\ 2 Dosen Pendidikan Geografi FKIP UHO
}

\begin{abstract}
Abstrak : Tujuan dalam penelitian ini adalah : 1) Mendeskripsikan aktifitas belajar IPS siswa kelas VII SMP Negeri Satap 2 Towea yang di ajar dengan menerapkan model pembelajaran kooperatif tipe Talking Stick pada materi pokok keragaman bentuk muka bumi, 2) Mendeskripsikan aktifitas mengajar guru IPS di kelas VII SMP Negeri Satap 2 Towea yang di ajar dengan menerapkan model pembelajaran kooperatif tipe Talking Stick pada materi pokok keragaman bentuk muka bumi, 3) Untuk mengetahui peningkatan hasil belajar IPS siswa kelas VII SMP Negeri Satap 2 Towea yang di ajar dengan menerapkan model pembelajaran kooperatif tipe Talking Stick pada materi keragaman bentuk muka bumi. Berdasarkan analisis data diperoleh kesimpulan bahwa : 1) Aktivitas belajar siswa dengan Model Pembelajaran Kooperatif tipe Talking Stick pada skor rata-rata aktivitas belajar siswa siklus I sebesar 2,5 termasuk kategori cukup meningkat pada siklus II menjadi 3,2 termasuk kategori baik; 2) Aktivitas mengajar guru dengan Penerapan Model Pembelajaran Kooperatif tipe Talking Stick pada skor rata-rata aktivitas mengajar guru siklus I sebesar 2,9 termasuk kategori cukup dan meningkat pada siklus II menjadi 3,1 kategori baik; 3) Ada peningkatan hasil belajar siswa kelas VII SMP Negeri Satap 2 Towea dari siklus I ke siklus II. Pada siklus I dari 23 orang siswa hanya 14 orang siswa yang tuntas dengan persentase ketuntasan $60,9 \%$ dengan nilai rata-rata 71 . Pada siklus II mengalami peningkatan yaitu dari 23 orang siswa ada 19 orang siswa yang tuntas dengan persentase ketuntasan $82,6 \%$ dengan nilai rata-rata 78 .
\end{abstract}

Kata Kunci; Model Pembelajaran, Proses, Hasi Belajar 
Jurnal Penelitian Pendidikan Geografi Volume 3 No. 4 Oktober 2018

\title{
APPLICATION OF COOPERATIVE LEARNING MODEL TYPE TALKING STICK TO IMPROVE RESULTS IPS STUDENT WITH DIVERSITY FORM OF EARTH SUBJECT CLASS VII STUDENTS OF SMP NEGERISATAP 2 TOWEA
}

(Class Action Research Against Students of Class VII SMP Negeri Satap 2 Towea)

\author{
Wa Rusna ${ }^{1}$, La Ode Nursalam² \\ 1 Alumni of Geography Education of Halu Oleo University \\ ${ }^{2}$ Geography Education Lecturer of Halu Oleo University
}

\begin{abstract}
The purpose of this research are: 1) To describe the learning activity of IPS of VII students of SMP Negeri Satap 2 Towea which is taught by applying cooperative learning model of Talking Stick type on the subject matter of diversity form of earth, 2) Describe the teaching activity of IPS teacher in grade VII SMP Negeri Satap 2 Towea is taught by applying cooperative learning model type Talking Stick on the subject matter of diversity form of earth, 3) To know the improvement of IPS learning outcomes of students of grade VII SMP Negeri Satap 2 Towea which is taught by applying cooperative learning model Talking Stick type on the material diversity form of earth. Based on data analysis, it can be concluded that: 1) Student learning activity with Cooperative Learning Model Talking Stick type on average score of student learning activity of cycle I is 2.5 including enough category increase in cycle II to 3,2 including good category; 2) Teacher teaching activity with Application of Cooperative Learning Model Talking Stick type on average score of teacher teaching activity cycle I of 2.9 including enough category and increase in cycle II to 3.1 good category; 3) There is an increase in student learning outcomes of grade VII SMP Negeri Satap 2 Towea from cycle I to cycle II. In the first cycle of 23 students only 14 students who completed with the percentage of completeness $60.9 \%$ with an average value of 71 . In cycle II has increased from 23 students there are 19 students who completed with a percentage of $82.6 \%$ with an average value of 78 .
\end{abstract}

\section{Keywords; Learning Model, Process, Learning Outcomes}

\section{PENDAHULUAN}

Kemajuan ilmu pengetahuan dan teknologi yang sangat pesat mengakibatkan perubahan di segala bidang kehidupan.Kemajuan ini tentu memberi dampak pada lembaga pendidikan. Lembaga pendidikan di tuntut untuk dapat menyelenggarakan proses pendidikan secara optimal dan aktif sebagai upaya untuk meningkatkan kualitas dan mutu pendidikan itu sendiri. Peningkatan kualitas dan mutu pendidikan yang baik di harapkan mampu melahirkan lulusan-lulusan yang mempunyai daya saing yang tinggi untuk menghadapi ketatnya tantangan dan persaingan di dunia kerja.Oleh karena itu, perbaikan-perbaikan yang membangun di bidang pendidikan harus terus di laksanakan guna mencapai kualitas pendidikan yang sesuai dengan harapan.
Upaya melakukan perbaikan di bidang pendidikan menjadi tanggung jawab semua pihak, salah satunya yaitu guru. Guru harus dapat melakukan suatu inovasi yang menyangkut tugasnya sebagai pendidik yang berkaitan dengan tugas mengajar siswa. Inovasi-inovasi yang di lakukan guru dalam tugasnya sebagai pendidik di harapkan dapat meningkatkan prestasi belajar siswa.Mengingat bahwa guru juga memberi pengaruh terhadap prestasi belajar siswa.

Dalam pelaksanaannya, proses belajar mengajar IPS tidak jarang di temukan kendala-kendala yang pada akhirnya menyebabkan rendahnya hasil belajar IPS siswa.Kondisi ini juga terjadi pada kelas VII SMP Negeri Satap 2 Towea. Guru masih menggunakan sistem penyampaian klasikal, yaitu sistem yang bertumpu pada aktivitas guru. Pada umumnya guru cenderung menggunakan metode ceramah dalam 
Jurnal Penelitian Pendidikan Geografi Volume 3 No. 4 Oktober 2018

mengajar. Bertumpunya proses belajar mengajar pada guru menimbulkan kurang tumbuh kembangnya sikap kemandirian belajar pada anak, sebab anak akan cenderung menganggap dirinya tergantung pada guru.

Salah satu cara yang dapat di tempuh berkaitan dengan inovasi tugas mengajar guru adalah guru hendaknya mempunyai kemampuan dalam mengembangkan strategi mengajarnya. Strategi mengajar di artikan sebagai suatu cara atau teknik yang di pakai oleh guru dalam menyajikan bahan ajar kepada siswa untuk mencapai tujuan pengajaran. Khususnya dalam hal ini adalah strategi untuk menunjang proses belajar mengajar IPS. Pemilihan strategi mengajar ini juga perlu di perhatikan. Guru hendaknya dapat memilih strategi mengajar yang di anggap sesuai dengan materi yang hendak di ajarkan. Hal ini di maksudkan agar pengajaran khususnya mata pelajaran IPS dapat berlangsusng secara efektif, efisien, dan tidak membosankan.

Berdasarkan hasil observasi awal pada guru IPS di sekolah di peroleh gambaran rendahnya hasil belajar siswa yang di tandai dengan rendahnya hasil belajar siswa dua tahun terakhir pada semester ganjil kelas VII SMP Negeri Satap 2 Towea pada materi pokok keragaman bentuk muka bumi.Dari KKM sekolah untuk mata pelajaran IPS yaitu 68. Pada tahun ajaran 2015/2016 hasil belajar siswa yang terdiri dari 20 orang siswa yang memperoleh nilai $\geq 68$ hanya 9 siswa atau $45 \%$. Sedangkan siswa yang memperoleh nilai < 68 sebanyak 11 siswa atau 55\%. Pada tahun ajaran 2016/2017 hasil belajar siswa yang terdiri dari 21 orang siswa yang memperoleh nilai $\geq 68$ hanya 10 siswa atau 48\%. Sedangkan siswa yang memperoleh nilai < 68 sebanyak 11 siswa atau 52\%. Nilai tersebut tentunya perlu perhatian dari berbagai pihak khususnya guru mata pelajaran IPS untuk melakukan alternatif baru dalam rangka perbaikan proses belajar mengajar untuk meningkatkan hasil belajar siswa.

Untuk mengantisipasi masalah di atas, maka guru dapat mengadakan perbaikan dan pengembangan suatu model pembelajaran yang dapat meningkatkan kemampuan dan pemahaman siswa dalam proses belajar mengajar dan membuat siswa dapat berperan aktif dalam menyelesaikan persoalanpersoalan.Salah satu model pembelajaran yang di harapkan dapat meningkatkan pemahaman siswa dalam proses belajar mengajar adalah model Pembelajaran Kooperatif Tipe Talking Stick. Model ini merupakan suatu model pembelajaran yang di dalamnya menuntut kerja sama siswa dalam menyelesaikan masalah yang di berikan oleh guru dengan cara memberi tongkat kepada siswa atau kelompok siswa, dan kelompok yang mendapat tongkat langsung menjawab pertanyaan yang satu dengan yang lainnya dalam kelompok dapat saling ketergantungan dalam tugas, tujuan dan penghargaan.

Berdasarkan uraian latar belakang di atas, maka penulis melakukan penelitian dengan judul "Penerapan Model Pembelajaran Kooperatif Tipe Talking Stick Untuk Meningkatkan Hasil Belajar Siswa Mata Pelajaran Ips Pada Materi Pokok Keragaman Bentuk Muka Bumi Siswa Kelas VII Smp Negeri Satap 2 Towea".

Menurut Saputra (2005: 50) bahwa pembelajaran kooperatif atau pembelajaran gotong royong adalah sistem pengajaran yang memberikan kesempatan kepada anak didik untuk bekerja sama dengan sesame siswa dalam tugas-tugas yang berstruktur. Dalam sistem ini guru bertindak sebagai fasilitator dalam penyelenggaraan proses belajar mengajar artinya meskipun siswa mengerjakan sesuatu tugas berstruktur secara bersama-sama dan bekerja sama dengan sesama siswa, tetapi guru tidak meninggalkan perannya begitu juga. Guru tetap menjadi pembimbing dan pengawas jalannya pembelajaran agar seluruh siswa dapat terlibat dalam proses pembelajaran tersebut.

Menurut Ponco Sujatmiko (2005: 145) menyatakan bahwa pembelajaran kooperatif adalah sistem pengajaran yang member kesempatan kepada anak didik untuk bekerja sama dengan temannya dalam tugas-tugas terstruktur. Smith yang di terjemahkan Munc Djunaedi (2002: 40) menggambarkan pelajaran kooperatif sebagai kerja sama siswa untuk 
Jurnal Penelitian Pendidikan Geografi Volume 3 No. 4 Oktober 2018

menyelesaikan pekerjaan di dalam kelas di mana siswa tersebut saling memperhatikan proses pembelajaran untuk menambah pengetahuan yang di milikinya.

Dengan demikian dapat di katakan bahwa pembelajaran kooperatif mempunyai ciri-ciri sebagai berikut:

1. Siswa belajar dalam kelompok, mendengarkan, mengemukakan pendapat, dan membuat keputusan secara bersama.

2. Kelompok siswa terdiri dari siswasiswa yang memiliki kemampuan yang tinggi, sedang dan rendah.

3. Jika dalam kelas terdapat siswa-siswa yang terdiri dari berbagai ras, suku, agama, budaya dan jenis kelamin yang berbeda-beda maka di upayakan agar dalam setiap kelompok terdapat ras, berbeda. suku, agama, dan jenis kelamin yang

4. Penghargaan lebih di utamakan pada kerja kelompok dari pada kerja heterogen.

Pembelajaran Kooperatif Tipe

Talking Stickmerupakan salah satu bentuk pembelajaran yang di dasarkan pada paham konstruvisme.Model pembelajaran kooperatif tipetalking stick adalah suatu model pembelajaran kelompok dengan bantuan tongkat, kelompok yang memegang tongkat terlebih dahulu wajib menjawab pertanyaan dari guru setelah siswa mempelajari materi pokoknya, selanjutnya kegiatan tersebut diulang terus-menerus sampai semua kelompok mendapat giliran untuk menjawab pertanyaan dari guru.

Dengan demikian dapat di katakan bahwa pembelajaran kooperatif talking stickmempunyai ciri-ciri sebagai berikut:

1. Guru menyiapkan sebuah tongkat.

2. Guru membagi siswa menjadi beberapa kelompok.

3. Guru menyampaikan materi pokok.

4. Guru mmberikan kesempatan kepada kelompok untuk membaca dan mempelajari materinya.

5. Siswa berdiskusi membahas masalah yang akan di teliti.

Dalam penerapan model pembelajaran kooperatif tipetalking stick ini, guru, membagi kelas menjadi kelompokkelompok dengan anggota 5 atau 6 orang yang heterogen. Kelompok dibentuk dengan mempertimbangkan keakraban, persahabatan atau minat, yang dalam topik selanjutnya menyiapkan dan mempersentasikan hasil diskusinya. Secara lengkap langkah-langkah model pembelajaran kooperatif tipe talking stick disajikan pada tabel 1.1 berikut:

Tabel 1.1. Langkah-langkah model pembelajaran kooperatif Tipe Talking Stick

\begin{tabular}{cl}
\hline No. & \multicolumn{1}{c}{ Kegiatan Siswa dan Guru } \\
\hline 1 & Guru menyiapkan sebuah tongkat \\
\hline 2. & $\begin{array}{l}\text { Guru menyampaikan materi pokok yang akan dipelajari, kemudian memberikan } \\
\text { kesempatan kepada kelompok siswa untuk membaca dan mempelajari materi pada buku } \\
\text { pegangannya atau buku paketnya }\end{array}$ \\
\hline 3. & $\begin{array}{l}\text { Setelah selesai membaca buku dan mempelajarinya guru mempersilahkan siswa untuk } \\
\text { menutup bukunya }\end{array}$ \\
\hline 4. & $\begin{array}{l}\text { Guru mengambil tongkat dan memberikan kepada salah satu siswa dalam kelompok } \\
\text { tertentu, setelah itu guru memberi pertanyaan dan siswa yang memegang tongkat }\end{array}$ \\
& $\begin{array}{l}\text { tersebut harus menjawabnya, demikian seterusnya sampai sebagian besar kelompok } \\
\text { siswa mendapat bagian untuk menjawab setiap pertanyaan dari guru }\end{array}$ \\
\hline 6. & Guru memberikan kesimpulan \\
\hline 7. & Evaluasi \\
\hline 8. & Penutup \\
\hline
\end{tabular}

(Sumber: Aqib, Zainal. 2013) 
Jurnal Penelitian Pendidikan Geografi Volume 3 No. 4 Oktober 2018

Kelebihan dari model pembelajaran kooperatif tipe talking stick, yaitu:

1. Menguji kesiapan siswa,

2. Melatih membaca dan memahami dengan cepat, dan

3. Agar lebih giat belajar (belajar dahulu).

Kelemahan dari model pembelajaran kooperatif tipe talking stick adalah membuat siswa senam jantung.

Menurut Ibrahim (2002: 23) menjelaskan bahwa dalam menerapkan model pembelajaran kooperatif tipe talking stick, langkah-langkah yang harus di lakukan oleh guru adalah sebagai berikut :

1. Guru menyiapkan tongkat.

2. Guru menyampaikan materi pembelajaran.

3. Guru mengelompokkan siswa yang terdiri dari 5 atau 6 orang siswa yang heterogen.

4. Guru membagi LKS pada tiap kelompok dan siswa menyelesaikan tugas yang di berikan oleh guru.

5. Setelah siswa menyelesaiakan LKS dan mempelajarinya, siswa mempersiapkan kelompok-kelompok masing-masing untuk presentase di depan kelas.

6. Guru mengambil tongkat dan memberikan tongkat kepada kelompok siswa dan kelompok terlebih dahulu mendapat tongkat langsung presentase di depan kelas, demikian seterusnya sampai kelompok mendapat giliran.

7. Guru memberikan kesimpulan.

8. Memberikan evaluasi

9. Menutup pelajaran.

Berdasarkan uraian di atas, dapat di simpulkan bahwa model pembelajaran kooperatif tipe talking stick adalah suatu model pembelajaran yang mengutamakan pada kerja sama dalam kelompok serta melatih siswa untuk mengeluarkan ide atau pendapat dalam diskusi kelompok dalam upaya untuk meningkatkan hasil belajar IPS.

\section{METODE PENELITIAN}

\section{Tempat dan Waktu Penelitian}

Penelitian ini telah di laksanakan pada bulan Agustus tahun 2017, tempat penelitian ini adalah SMP Negeri Satap 2
Towea Kabupaten Munadi kelas VII pada semester ganjil tahun ajaran 2017/2018 yang berlangsung pada tanggal 21 Agustus sampai 12 September 2017.

\section{Subyek Penelitian}

Adapun subyek penelitian ini adalah siswa kelas VII SMP Negeri Satap 2 Towea dengan jumlah 23 orang.Penetapan subyek ini di dasarkan pada pertimbangan hasil belajar siswa karena sebagian besar hasil belajar siswa pada materi pokok keragaman bentuk muka bumi belum mencapai Kriteria Ketuntasan Minimal (KKM).

\section{Jenis Penelitian}

Jenis penelitian ini adalah penelitian tindakan kelas (Classroom Action Research). Karakteristik yang khas dari penelitian ini adalah adanya tindakan yang berulang untuk melakukan perbaikan dalam proses belajar mengajar. PTK ini di lakukan dengan menerapkan model pembelajaran kooperatif tipe talking stick sebagai alternatif tindakan untuk meningkatkan hasil belajar IPS siswa kelas VII SMP Negeri Satap 2 Towea pada materi pokok keragaman bentuk muka bumi.

\section{Faktor Yang Diteliti}

Faktor yang di teliti dalam penelitian ini adalah:

1. Faktor siswa: yaitu untuk melihat hasil belajar siswa dalam mempelajari IPS khususnya pada materi pokok tentang keragaman bentuk muka bumi.

2. Faktor guru: meliputi Persiapan materi pelajaran dan kesiapan guru melaksanakan pembelajaran kooperatif tipe talking stick.

\section{Desain Penelitian}

Penelitian ini merupakan Penelitian Tindakan Kelas (PTK) yang melakukan proses pengkajian berdaur atau bersiklus dari berbagai kegiatan. Penelitian tindakan kelas ini dilaksanakan terdiri dari 2 (dua) siklus. Tiap siklus dilaksanakan indikator 
Jurnal Penelitian Pendidikan Geografi Volume 3 No. 4 Oktober 2018

yang ingin dicapai setiap faktor yang akan diselidiki.

Dalam penelitian ini yang mengajar adalah peneliti pada kelas tersebut berkolaborasi dengan guru sebagaiobserver/pengamat. Desain penelitian dalam penelitian tindakan kelas yang dilakukan adalah sebagai berikut:

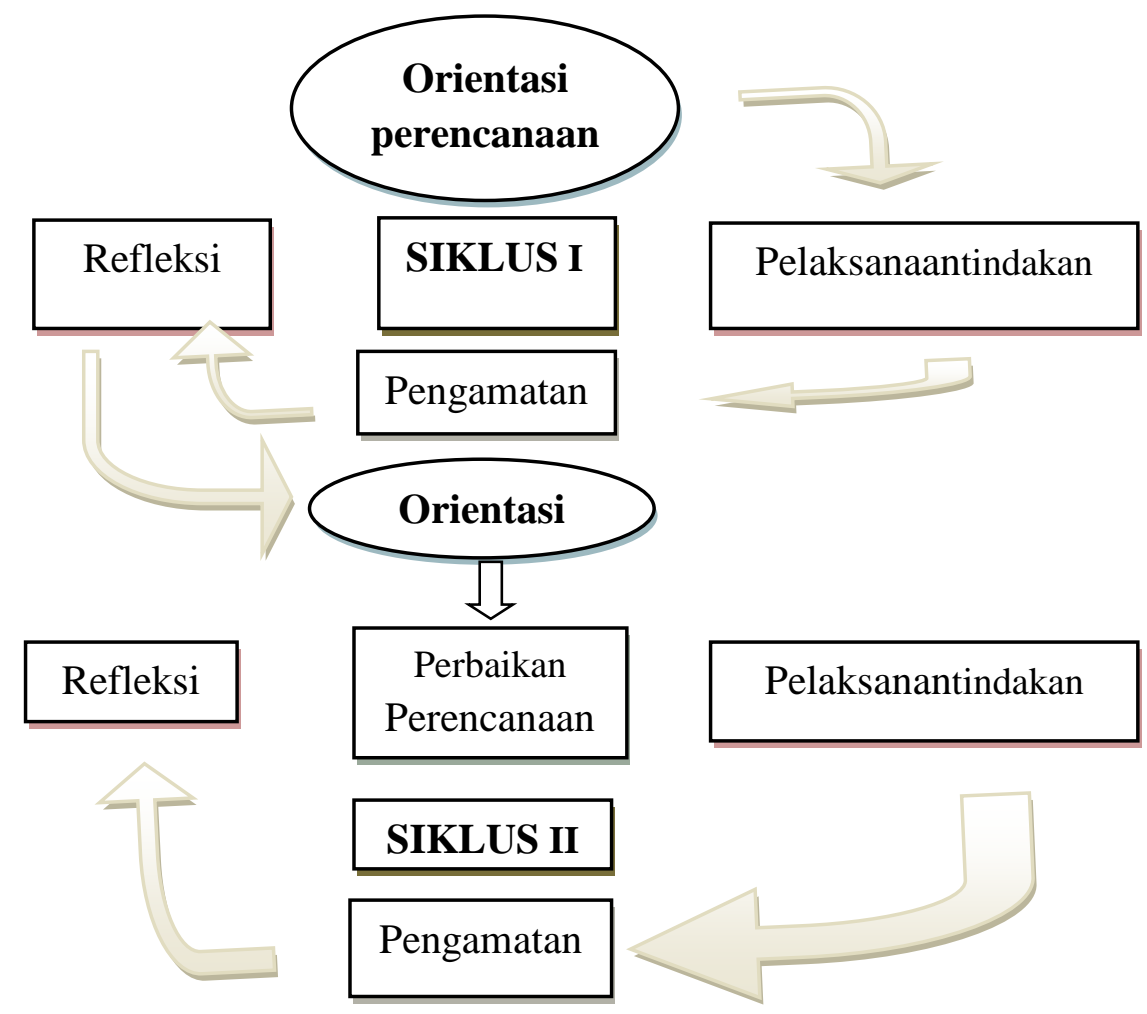

Gambar 2.1 Desain Penelitian Tindakan Kelas (Iskandar,2012:67)

Menurut Wardani (2004:212) bahwa langkah dalam Penelitian Tindakan Kelas (PTK) merupakansatu daur atau siklus yang terdiri dari:

1. Perencanaan (Planning)

2. Pelaksanaan tindakan (Action)

3. Observasi dan evaluasi (Observation and Evaluation)

4. Refleksi (Reflection).

Secara rinci prosedur penelitian tindakan kelas setiap siklus adalah sebagai berikut:

1. Perencanaan (Planning)

Pada tahap perencanaan kegiatan dilakukan langkah-langkah sebagai berikut:

a) Membuat perencanaan pengajaraan berupa Rencana Perbaikan Pembelajaran (RPP) dengan model pembelajaran kooperatif tipeTalking Stick. b) Mempersiapkan alat peraga berupa lembar observasi keaktifan dan partisipasi aktif siswa dalam kegiatan pembelajaran.

c) Alat evaluasi berupa penilaian proses dan hasil belajar (produk) untuk mengetahui hasil yang dicapai siswa setelah mengikuti kegiatan pembelajaran.

2. Tindakan (Action)

Kegiatan yang dilaksanakan dalam tahapan ini adalah melaksanakan kegiatan pembelajaran sebagaimana yang telah direncanakan yaitu dengan menerapkan Model Pembelajaran kooperatif tipe Talking Stick yang mengacu pada skenario pembelajaran

3. Pengamatan (Observation)

Pengamatan dilakukan dalam penelitian ini terdiri atas:

a) Melakukan observasi terhadap aktitiftas guru dan siswa dengan 
Jurnal Penelitian Pendidikan Geografi Volume 3 No. 4 Oktober 2018

memakai format observasi yang sudah disiapkan.

b) Menilai hasil tindakan dengan menggunakan format LKS.

\section{Refleksi (Reflection)}

Peneliti melaksanakan diskusi dengan pengamat untuk merefleksi hasil observasi dan evaluasi yang dilakukan. Refleksi dilakukan untuk mengkaji tujuan yang telah dan belum di capai.Hasil refleksi digunakan untuk menetapkan langkahlangkah lebih lanjut pada siklus berikutnya.

\section{Data dan Tehnik Pengumpulan Data}

\section{Sumber Data}

Sumber data penelitian adalah guru dan siswa yang meliputi: a) hasil observasi aktivitas belajar siswa; b) hasil observasi aktivitas mengajar guru;dan c) hasil belajar siswa.

2. Jenis Data

Jenis data yang di peroleh adalah data kuantitatif dan data kualitatif.Data kuantitatif di peroleh dari tes hasil belajar sedangkan data kualitatif di peroleh dari lembar observasi.

3. Teknik Pengumpulan Data

Teknik pengumpulan data dalam penelitian ini adalah:

a) Data mengenai aktivitas siswa di ambil dengan menggunakan lembar observasi dengan cara memberikan skor pada aspek aktivitas yang di lakukan untuk siswa sesuai dengan kriteria yang telah di tentukan.

b) Data mengenai hasil belajar IPS di ambil dengan menggunakan tes hasil belajar (tes siklus) dengan bentuk tes berupa tes esay yang mencakup semua indikator pembelajaran pada siklus I serta siklus II.

\section{Teknik Analisis Data}

Data dalam penelitian ini di analisis dengan menggunakan analisis deskriptif dan kuantitatif. Analisis deskriptif kualitatif di gunakan untuk memberikan penjelasan mengenai aktivitas siswa serta kemampuan guru selama proses pembelajaran berlangsung, sedangkan analisis deskriptif kuantitatif di gunakan untuk menyajikan persentase aktivitas guru dalam mengelola pembelajaran, persentase aktivitas siswa dan persentase ketuntasan hasil belajar siswa.

1. Menentukan hasil belajar siswa secara individual

Untuk menentukan nilai hasil belajar siswa dapat menggunakan rumus: Dalam menentukan nilai hasil belajar siswa dapat menggunakan rumus:

$$
X i=\frac{s p i}{S m} \times 100
$$

Keterangan:

$X \mathrm{i}=$ nilai yang diperoleh siswa ke- $\mathrm{i}$

Spi $=$ skor yang diperoleh siswa ke-i

$\mathrm{Sm}=$ skor maksimal

(Usman dan Setiawati, 2001)

2. Menentukan nilai rata-rata hasil belajar siswa dengan rumus:

Nilai rata-rata $=$ skor total yang di peroleh siswa / jumlah siswa

(Suparno, 2008: 81)

3. Menentukan tingkat pencapaian ketuntasan belajar secara klasikal

Persentase jumlah siswa yang hasil belajarnya sudah tuntas dapat menggunakan rumus sebagai berikut:

$\%$ Tuntas $=\left(\sum\right.$ тв $) / \mathrm{Nx} 100 \%$

Keterangan:

$\sum \mathrm{TB}=$ jumlah siswa yang tuntas belajar

$\mathrm{N}=$ jumlah siswa secara keseluruhan

(Sudjana, 2002)

4. Mengklasifikasikan rata-rata skor aktivitas siswa sebagai berikut :

$1 \leq \mathrm{Xi}<2 \quad$ : Kategori Kurang

$2 \leq \mathrm{Xi}<3 \quad$ : Kategori Cukup

$3 \leq \mathrm{Xi}<4 \quad$ : Kategori Baik

$\mathrm{Xi}=4 \quad$ : Kategori Sangat Baik

(Susetyo, 2008) 
Jurnal Penelitian Pendidikan Geografi Volume 3 No. 4 Oktober 2018

Penjelasan kategori rata-rata aktivias siswa adalah sebagai berikut :

a. Kategori sangat baik jika dalam satu kelompok terdapat lima sampai enam siswa atau semua siswa mampu menerapkan semua satuan aktivitas yang dinilai.

b. Kategori baik jika dalam satu kelompok terdapat satu sampai dua siswa yang kurang mampu menerapkan semua satuan aktivitas yang dinilai.

c. Kategori cukup jika dalam satu kelompok terdapat tiga sampai empat siswa yang kurang mampu menerapkan semua satuan aktivitas yang dinilai.

d. Kategori kurang jika dalam satu kelompok terdapat lima sampai enam siswa yang kurang mampu menerapkan semua satuan aktivitas yang dinilai.

\section{Indikator Keberhasilan}

Indikator keberhasilan dalam penelitian ini dapat di lihat dari dua segi, yaitu:

1. Dari Segi Proses

Penelitian ini di katakan berhasil jika skor rata-rata aktivitas guru dan siswa minimal 3,0

2. Dari Segi Hasil

a) Secara individu, jika hasil belajar IPS siswa kelas VII SMP Negeri Satap 2 Towea yang menjadi subyek penelitian telah mencapai ketuntasan belajar minimal 68 sesuai dengan KKM yang di tentukan di sekolah.

b) Secara klasikal, jika siswa mencapai ketuntasan belajar minimal $80 \%$

\section{HASIL PENELITIAN}

\section{Hasil Analisi Data Siklus 1 \\ a. Data Aktivitas Belajar Siswa Siklus 1}

Untuk mendapatkan gambaran ratarata aktivitas belajar siswa selama pembelajaran pada siklus I pada pertemuan I dan II dapat dilihat pada Gambar 3.1berikut :

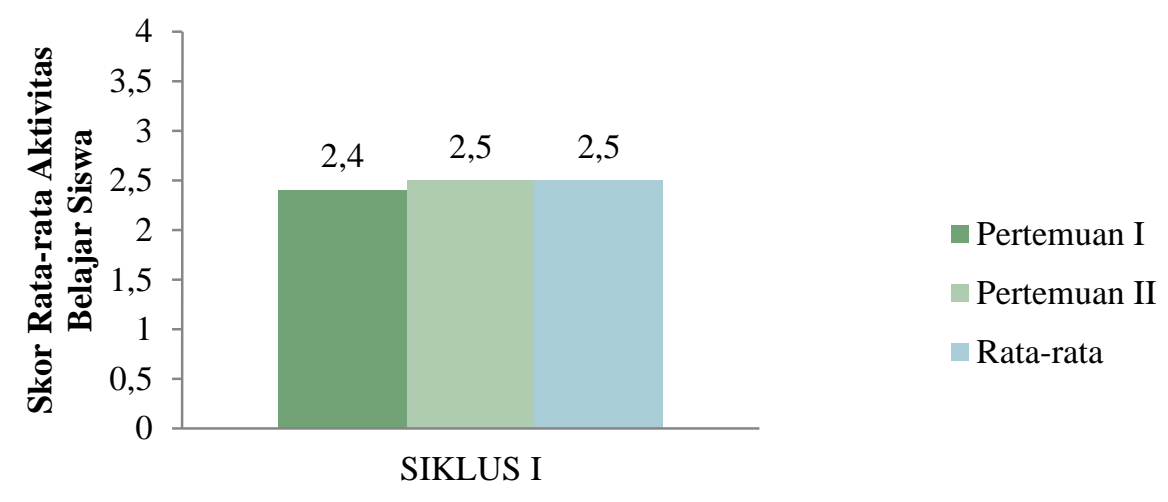

\section{Gambar 3.1 Grafik Skor Rata-rata Aktivitas Belajar Siswa Siklus I}

Berdasarkan gambar 3.1 di atas tentang hasil observasi aktifitas belajar siswa dapat diperoleh gambaran bahwa, hasil aktifitas belajar siswa tersebut masih belum memenuhi kriteria ketuntasan minimal yaitukarena rata-rata aktifitas belajar siswa masih mencapi nilai 2,5 yang berkategorikan Cukup.

\section{b. Data Aktivitas Mengajar Guru Siklu I}

Untuk mendapatkan gambaran rata-rata aktifitas mengajar guru selama pembelajaran pada siklus I pada pertemuan I dan II dapat dilihat pada gambar 3.2 berikut: 
Jurnal Penelitian Pendidikan Geografi Volume 3 No. 4 Oktober 2018

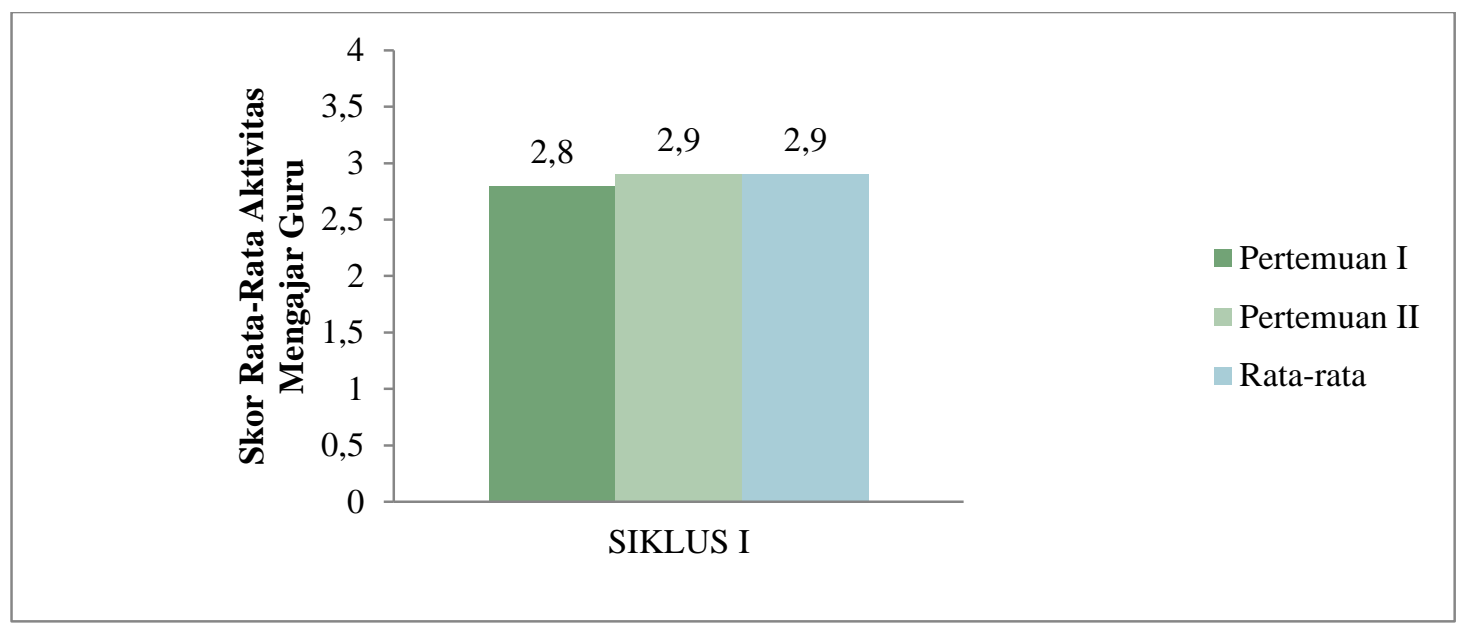

Gambar 3.2 Grafik Skor Rata-rata Aktivitas Mengajar Guru Siklus I

Berdasarkan gambar 3.2 diatas tentang hasil observasi aktifitasmengajar guru dapat diperoleh gambaran bahwa, hasil aktifitas guru tersebut masih belum memenuhi kriteria ketuntasan minimal yaitu 3,0, karena rata-rata aktifitas guru masih mencapai rata-rata 2,9 yang berkategorikan Cukup.

\section{c. Data Hasil Belajar Siswa Siklus I}

Berdasarkan analisis data hasil belajar siswa pada siklus I diperoleh hasil sebagaimana disajikan pada tabel berikut:

Tabel 3.1 Data Analisis Ketuntasan Hasil Belajar Siswa Siklus I

\begin{tabular}{c|c|c}
\hline NO & Aspek Perolehan & Hasil \\
\hline 1 & Skor tertinggi & 95,7 \\
\hline 2 & Skor terendah & 43,5 \\
\hline 3 & Banyaknya siswayang tuntas & 14 (orang) \\
\hline 4 & Banyaknya siswa yang tidak tuntas & 9 (orang) \\
\hline 5 & Nilai rata-rata & $71 \%$ \\
\hline 6 & Persentase tuntas & $60,9 \%$ \\
\hline 7 & Persentase belum tuntas & $39,1 \%$ \\
\hline
\end{tabular}

( Sumber : Data diolah tahun 2018 )

Untuk lebih jelasnya gambaran hasil belajar siswa kelas VII yang diajar dengan menerapkan Model Pembelajaran Kooperatif tipe Talking Stick pada siklus I dapat dilihat pada gambar 3.3 berikut: 
Jurnal Penelitian Pendidikan Geografi Volume 3 No. 4 Oktober 2018

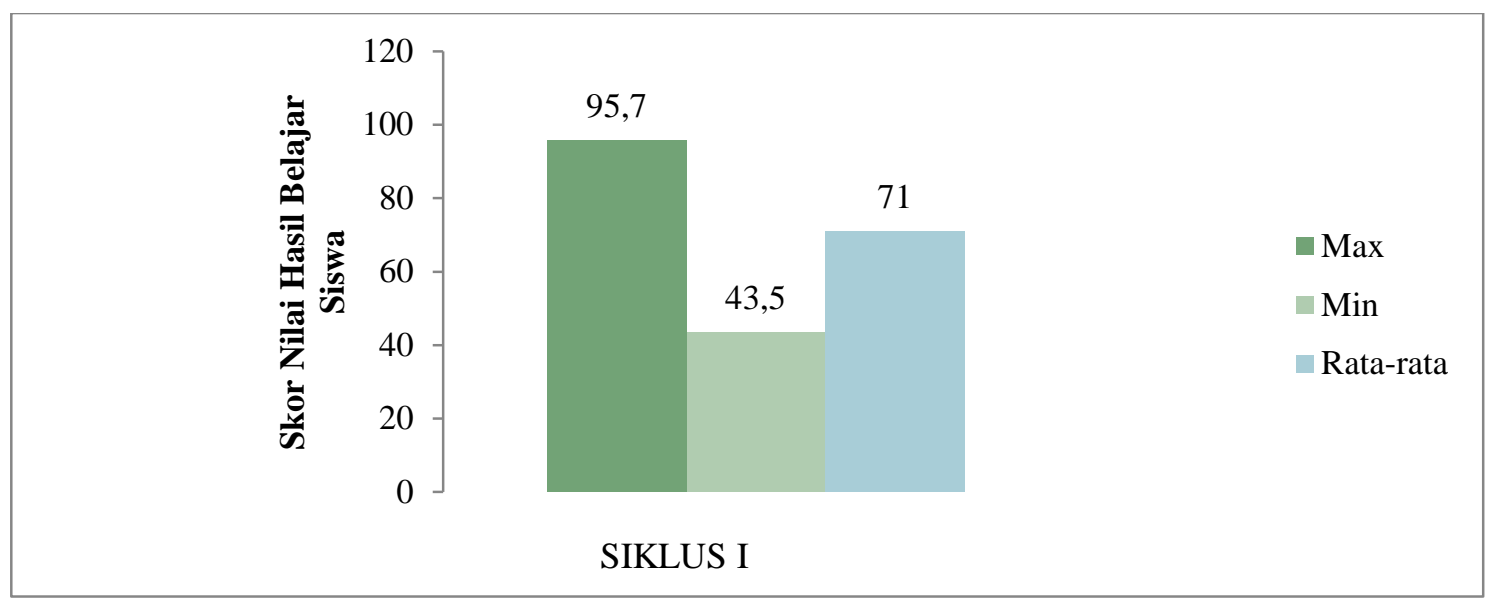

Gambar 3.3 Grafik Nilai Hasil Belajar Siswa Siklus I

Selanjutnya berdasarkan analisis diperoleh hasil sebagaimana disajikan pada ketuntasan belajar siswa pada siklus I gambar 3.4 berikut:

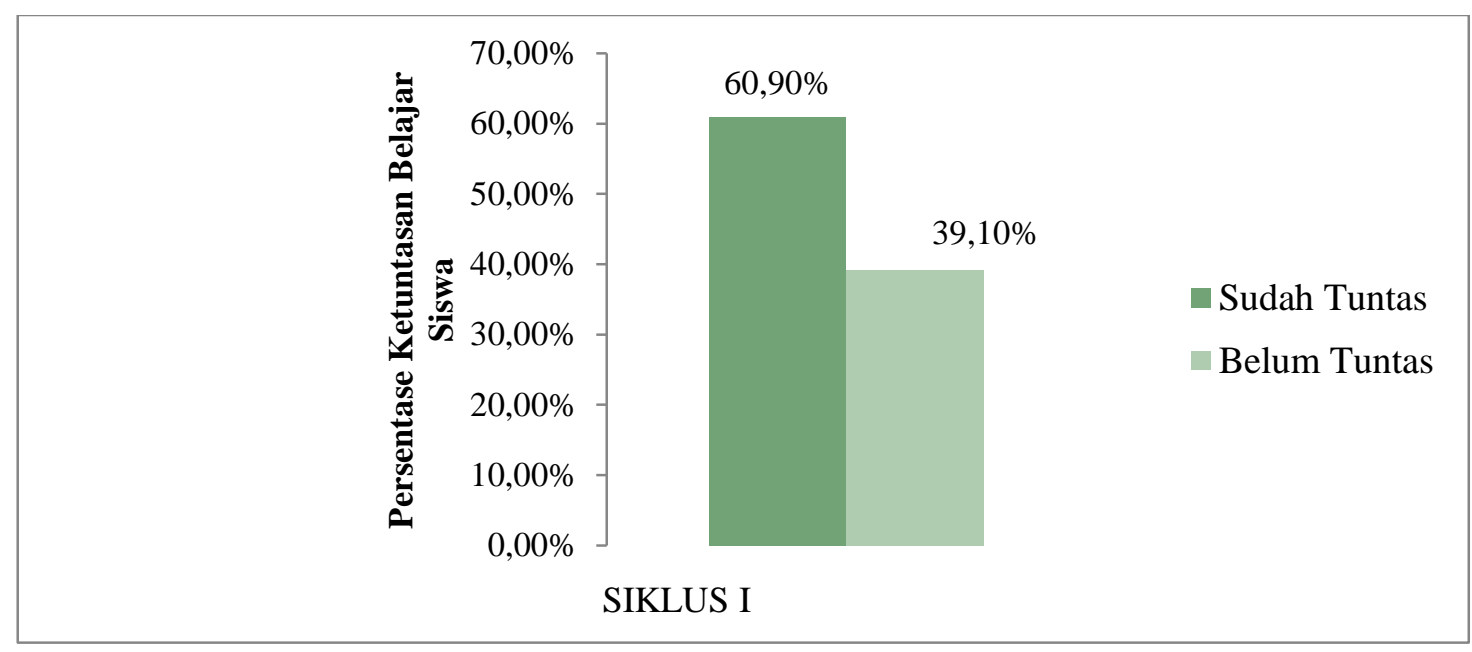

Gambar 3.4 Grafik Presentase Ketuntasan Belajar Siswa Siklus I

Tabel 3.1 dan gambar 3.4 diatas menunjukan bahwa ketuntasan belajar siswa pada siklus I yang memperoleh skor antara $0-64$ berjumlah 9 orang dengan persentase $39,10 \%$, sedangkan siswa yang telah memperoleh skor antara $65-$ 100 berjumlah 14 orang dengan persentase ketuntasan mencapai $60,90 \%$, namun belum mencapai indikator ketuntasan keberhasilan dimana $80 \%$ siswa mencapai ketuntasan belajar.

Dari hasil refleksi pada hasil belajar siswa siklus I, diantaranya adalah; 1) siswa kurang mendengarkan guru menyampaikan materi pembelajaran; 2) siswa masih kurang terlibat Tanya jawab; 3) Siswa kurang menanyakan hal-hal yang belum di mengerti; 4) Siswa kurang aktif bekerja sama dengan kelompoknya dalam menyelesaikan LKS; serta 5) siswa kurang aktif dalam menyimpulkan materi yang telah di bahas.

Setelah melakukan analisis dan refleksi hasil belajar siswa pada siklus I, peneliti mencoba melakukan perbaikan dalam proses belajar mengajar agar pada siklus selanjutnya siswa yang belum maupun yang sudah memenuhi ketuntasan belajar dapat meningkat lagi seperti yang diharapkan. 
Jurnal Penelitian Pendidikan Geografi Volume 3 No. 4 Oktober 2018

2. Hasil Analisis Data Siklus II

a. Data Aktivitas Belajar Siswa Siklus II

Untuk mendapatkan gambaran rata-

rata aktifitas belajar siswa selama pembelajaran pada siklus II pada pertemuan III dan IV dapat dilihat pada Gambar 3.5 berikut:

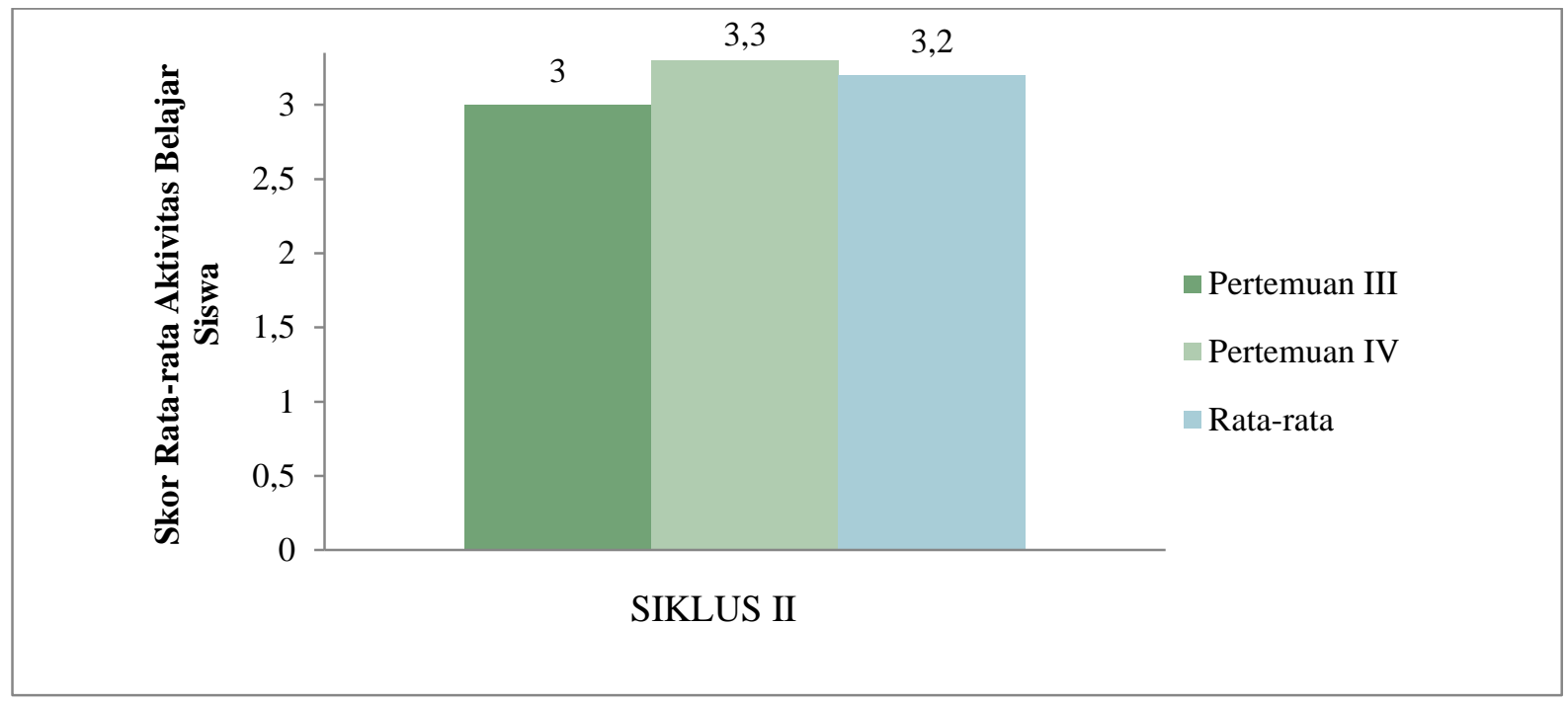

Gambar 3.5 Grafik Skor Rata-rata Aktivitas Belajar Siswa Siklus II

Berdasarkan gambar 3.5 diatas menunjukan bahwa aktifitas belajar siswa telah memenuhi kriteria ketuntasan minimal yaitu 3,0.Dimana aktifitas belajar siswa telah mencapai rata-rata 3,2 yang berkategorikan Baik.

\section{b. Data Aktivitas Mengajar Guru Siklus II}

Untuk mendapatkan gambaran ratarata aktivitas guru selama pembelajaran pada siklus II pada pertemuan III dan IV dapat dilihat pada Gambar 3.6 berikut:

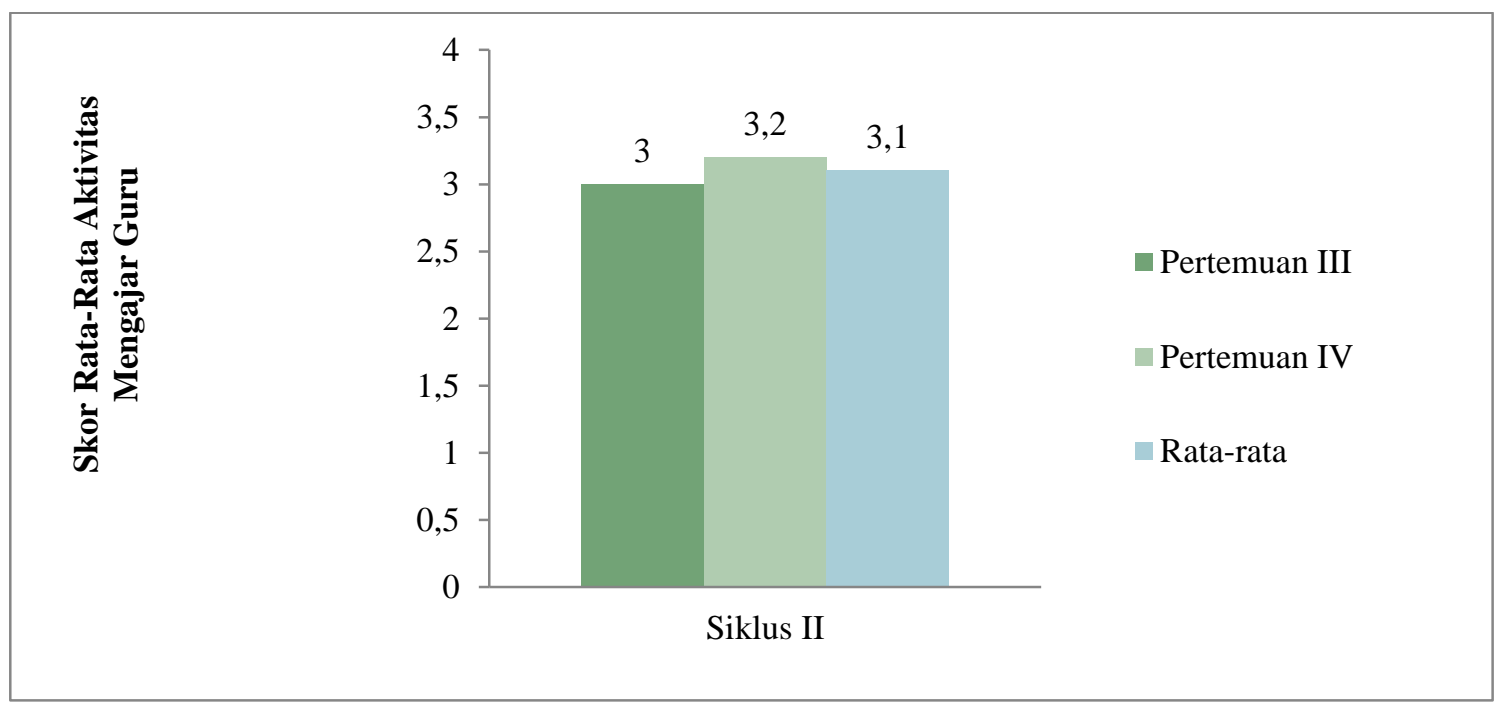

Gambar 3.6 Grafik Skor Rata-rata Aktivitas Mengajar Guru Siklus II

Berdasarkan gambar 3.6 diatas menunjukan bahwa aktivitas guru telah memenuhi kriteria ketuntasan minimal yaitu 3,0.Dimana aktivitas guru telah 
Jurnal Penelitian Pendidikan Geografi Volume 3 No. 4 Oktober 2018

mencapai rata-rata3,2 yang berkategorikan Baik.

\section{c. Data Hasil Belajar Siswa Siklus II}

Berdasarkan hasil analisis data hasil belajar siswa pada siklus II diperoleh hasil sebagaimana disajikan pada tabel 3.2 berikut:

Tabel 3.2 Data Analisis Ketuntasan Hasil Belajar Siswa Siklus II

\begin{tabular}{c|c|c}
\hline No & Aspek Perolehan & Hasil \\
\hline 1 & Skor tertinggi & 95,7 \\
\hline 2 & Skor terendah & 52,2 \\
\hline 3 & Banyaknya siswa yang tuntas & 19 (orang) \\
\hline 4 & Banyaknya siswa yang tidak tuntas & 4 (orang) \\
\hline 5 & Nilai rata-rata & $78 \%$ \\
\hline 6 & Persentase tuntas & $82,6 \%$ \\
\hline 7 & Persentase belum tuntas & $17,4 \%$ \\
\hline
\end{tabular}

Untuk lebih jelasnya gambaran hasil belajar siswa kelas VII yang diajar dengan menerapkan Model Pembelajaran Kooperatif tipe Talking Stick materi pokok
Keragaman Bentuk Muka Bumi pada siklus II dapat dilihat pada gambar 3.7 berikut:

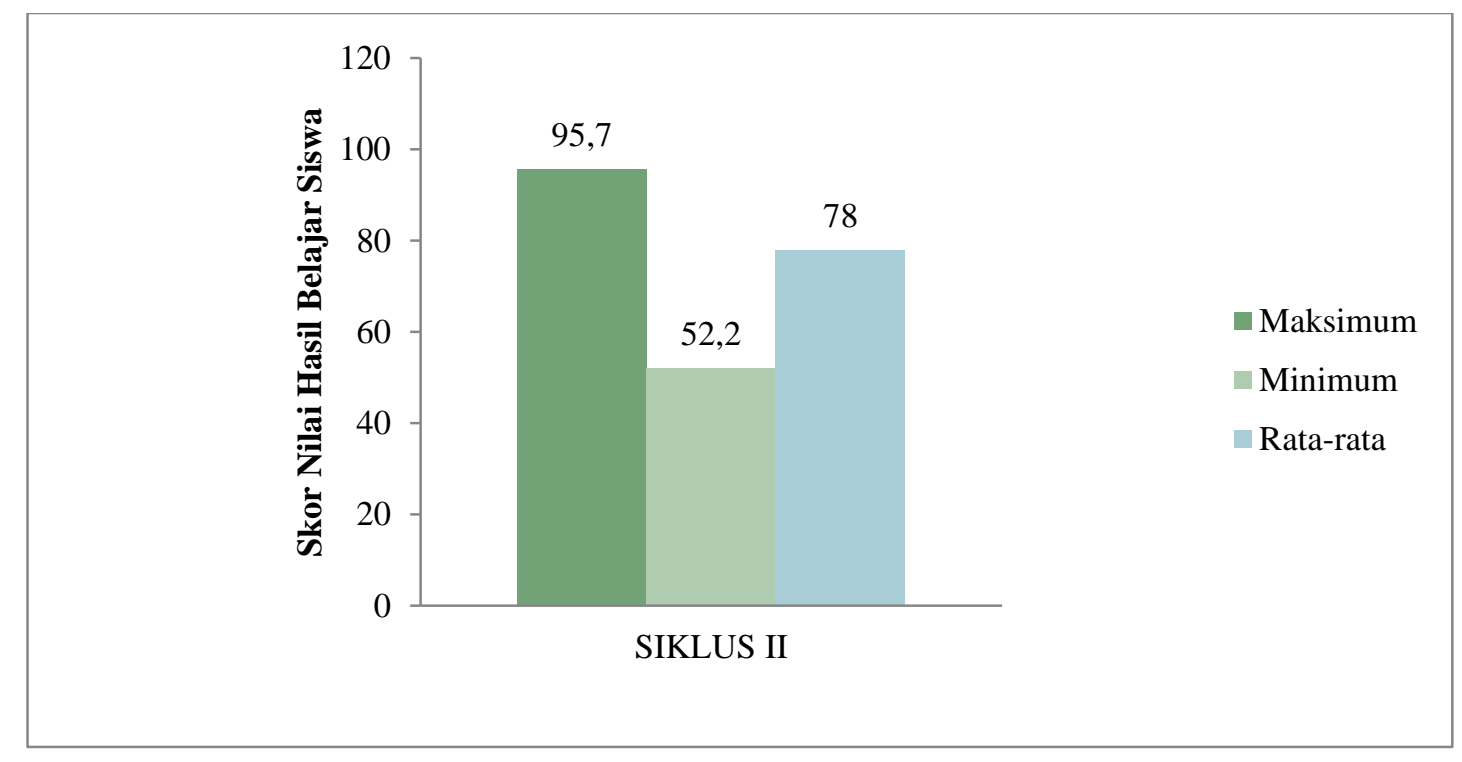

Gambar 3.7 Grafik Nilai Hasil Belajar Siswa Siklus II

Selanjutnya berdasarkan analisis ketuntasan belajar siswa pada siklus II diperoleh hasil sebagaimana disajikan pada gambar 3.8 berikut: 
Jurnal Penelitian Pendidikan Geografi Volume 3 No. 4 Oktober 2018

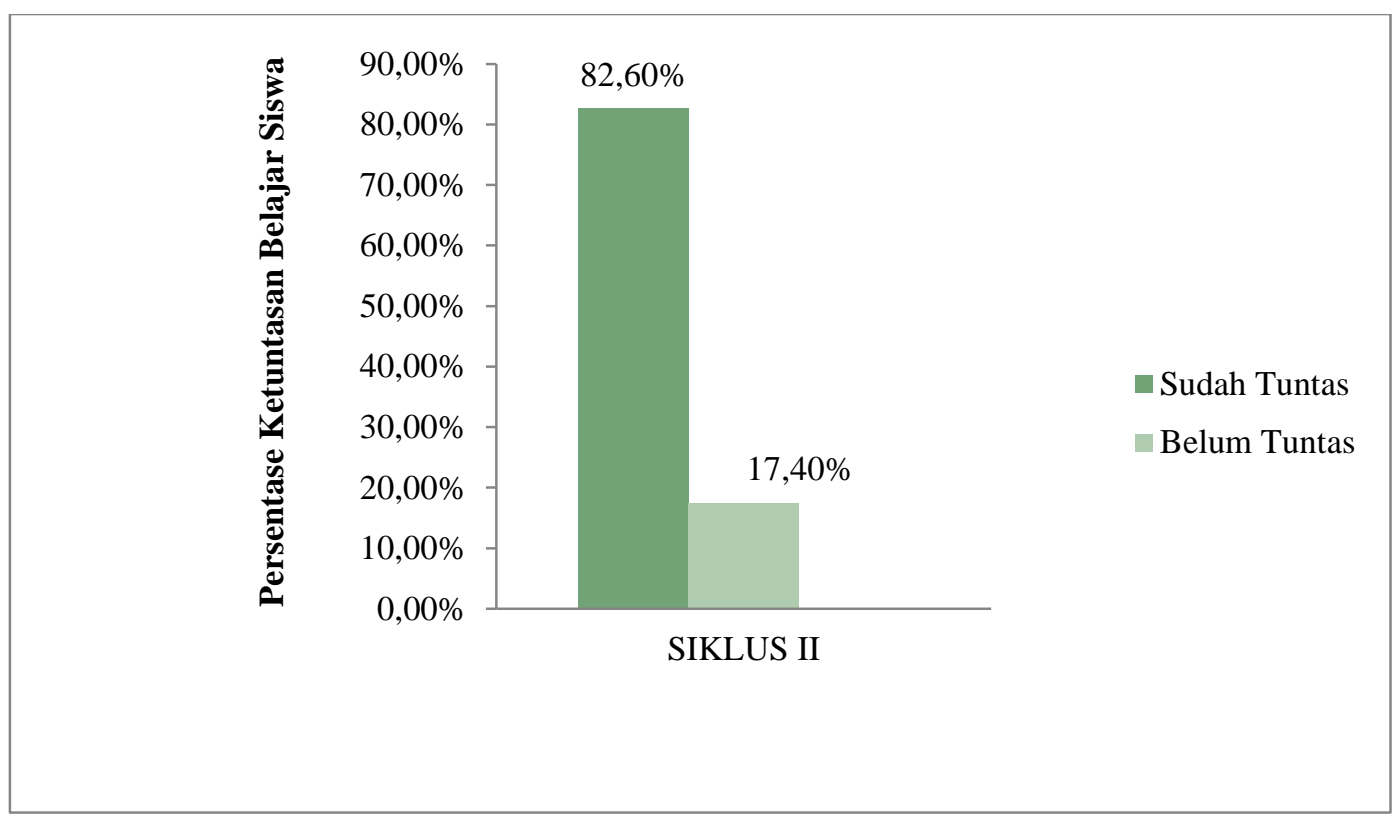

Gambar 3.8 Grafik Presentase Ketuntasan Belajar Siswa Siklus II

Tabel 3.2 dan gambar 3.8diatas menunjukan bahwa ketuntasan belajar siswa pada siklus II yang telah memperoleh skor antara $0-64$ berjumlah 4 orang dengan presentase $17,4 \%$, sedangkan siswa yang telah memperoleh skor antara $65-$ 100 berjumlah 19 orang dengan presentase $82,6 \%$. Hasil ini sudah lebih baik jika dibandingkan dengan skor perolehan nilai siswa pada siklus I. Dalam hal ini indikator ketuntasan belajar siswa telah tercapai atau berhasil, dimana secara klasikal, yaitu jika nilai siswa yang telah mencapai KKM (68) adalah $80 \%$, maka dikatakan hasil penelitian telah tercapai dan berhasil.

\section{PEMBAHASAN}

\section{Aktivitas Belajar Siswa Selama KBM Berlangsung}

Berdasarkan permasalahan pertama tentang bagaimana gambaran aktivitas belajar siswa kelas VII SMP Negeri 2 Towea dalam proses belajar mengajar pada materi pokok keragaman bentuk muka bumi yang diajar dengan menerapkan Model Pembelajaran Kooperatif tipe Talking Stick dapat dijelaskan berdasarkan hasil pengamatan pada setiap siklus baik siklus I maupun siklus II yang menunjukan peningkatan kearah yang lebih baik. Peningkatan aktivitas belajar siswa tersebut menunjukan adanya minat dan antusiasme siswa dalam mengikuti proses pembelajaran pada materi pokok keragaman bentuk muka bumi dengan menerapakan Model Pembelajaran Kooperatif tipe Talking Stick. Pada siklus I berdasarkan hasil analisis deskriptif terhadap aktivitas belajar siswa menunjukan skor rata-rata aktivitas belajar siswa pada siklus I sebesar 2,5 yang berkategori Cukup. Pada siklus I ada beberapa aktivitas belajar siswa yang masih tergolong kurang dimana siswa belum terbiasa dengan Model Pembelajaran Kooperatif tipe Talking Stick pada materi pokok keragaman bentuk muka bumi diantaranya: Siswa kurang mendengarkan dan memperhatikan guru menyampaikan materi pembelajaran, Siswa kurang aktif menjawab pertanyaan yang di berikan oleh guru, Siswa kurang mendengarkan penyampaian langkah-langkah pembelajaran tipetalking stick, Siswa kurang aktif berdiskusi dengan teman kelompoknya dalam menyelesaikan masalah, Siswa kurang menyimak dan menanggapi hasil diskusi kelompok lain, Siswa kurang aktif dalam menyimpulkan materi yang telah dibahas. Berdasarkan hasil refleksi pada siklus I ditemukan beberapa aktivitas siswa yang masih belum terlaksana dengan baik.Oleh karena itu dilakukan perbaikan pada siklus selanjutnya. 
Jurnal Penelitian Pendidikan Geografi Volume 3 No. 4 Oktober 2018

Pada siklus II guru mulai menekankan kepada siswa agar siswa mendengarkan dan memperhatikan guru menyampaikan materi pembelajaran, agar siswa aktif menjawab pertanyaan yang di berikan oleh guru, agar siswa mendengarkan penyampaian langkah-langkah pembelajaran tipe talking stick, agar siswa aktif berdiskusi dengan teman kelompoknya dalam menyelesaikan masalah, agar siswa menyimak dan menanggapi hasil diskusi kelompok lain, agar siswa aktif dalam menyimpulkan materi yang telah di bahas, karena kelompok yang mempersentasikan hasil diskusinya dengan baik akan mendapatkan penghargaan atau hadiah dari guru. Dari hasil analisis deskriptif terhadap skor rata-rata aktivitas belajar siswa pada siklus II menunjukan adanya peningkatan yang signifikan dari aktivitas belajar siswa siklus I, dimana skor rata-rata aktivitas belajar siswa pada siklus II sebesar 3,2 yang berkategori Baik.Hal ini menunjukan bahwa penelitian telah berhasil karena telah memenuhi standar minimal aktivitas siswa yaitu 3,0.

\section{Aktivitas Mengajar Guru}

yaitu bagaimana gambaran aktivitas mengajar guru dengan menerapkan Model Pembelajaran Kooperatif tipe Talking Stickpada materi pokok Keragaman Bentuk Muka Bumi, dapat dijelaskan berdasarkan hasil pengamatan aktivitas mengajar guru pada setiap siklus baik siklus I maupun siklus II yang menunjukan peningkatan kearah yang lebih baik.

Pada siklus I berdasarkan analisa deskriptif aktivitas mengajar guru menunjukan skor rata-rata aktivitas guru sebesar 2,9yang berkategori cukup dimana aktivitas guru pada siklus I yang masih rendah berdasarkan hasil refleksi diantaranya adalah: guru kurang menuliskan tujuan pembelajaran dan pokok materi yang akan dipelajari, guru kurang memberikan apersepsi kepada siswa, guru kurang membimbing siswa untuk membahas permasalahan yang disajikan dalam LKS, guru kurang meminta siswa menyimpulkan materi yang telah di bahas.

Berdasarkan hasil refleksi terhadap aktivitas mengajar guru, dengan mengetahui kekurangan-kekurangan pada siklus I, guru memperbaiki cara mengajarkan materi pembelajaran yang sesuai dengan Model Pembelajaran Kooperatif tipe Talking Stickpada materi pokok keragaman bentuk muka bumi sehingga diharapkan pada pertemuan selanjutnya diperoleh peningkatan aktivitas guru pada siklus selanjutnya.

Pada siklus II guru mulai memperbaiki cara mengajar yaitu guru mulai menuliskan tujuan pembelajaran dan pokok materi yang akan di pelajari, guru mulai memberikan apersepsi kepada siswa, guru mulai membimbing siswa untuk membahas permasalahan yang telah di sajikan dalam LKS, guru mulai meminta siswa menyimpulkan materi yang telah di bahas. Aktivitas mengajar guru menunjukan peningkatan dimana pada siklus II skor ratarata aktivitas guru memperoleh nilai sebesar 3,1 yang berkategori baik. Hasil analisis dan pengamatan pada siklus II ini menunjukan adanya peningkatan aktivitas mengajar guru dengan menerapkan Model Pembelajaran Kooperatif tipe Talking Stickpada materi pokok keragaman bentuk muka bumi.Hal ini menunjukan bahwa penelitian telah berhasil karena telah memenuhi standar minimal aktivitas mengajar guru yaitu 3,0 .

\section{Hasil Belajar Siswa}

Berdasarkan permasalahan ketiga yaitu apakah ada peningkatan hasil belajar siswa yang diajar dengan penerapan Model Pembelajaran Kooperatif tipe Talking Stickpada materi pokok keragaman bentuk muka bumi pada siswa kelas VII SMP Negeri 2 Towea, dapat dijelaskan bahwa berdasarkan hasil analisis deskriptif kuantitatif yang dilakukan terhadap hasil belajar siswa pada setiap siklus cenderung mengalami peningkatan kearah yang lebih baik.

Pada siklus I berdasarkan hasil tes belajar siswa diperoleh nilai minimum sebesar 43,5; nilai maksimum 95,7; rata-rata 
hasil belajar siswa 71\%. Secara klasikal dari 32 siswa yang mencapai persentase ketuntasan hasil belajar yaitu 14 siswa atau $60,9 \%$ yang mencapai nilai $\geq 68$ sesuai dengan nilai KKM IPS dan terdapat 9 orang siswa dengan persentase $39,1 \%$ siswa yang nilainya belum mencapai KKM yang ditentukan oleh sekolah yaitu 68. Persentase ketuntasan pada siklus I ini belum mencapai target peneliti yaitu mencapai ketuntasan belajar secara klasikal minimal $80 \%$.

Berdasarkan refleksi dengan melihat aktivitas siswa dan hasil belajar pada siklus I tersebut, dapat diambil suatu kesimpulan bahwa dalam proses pembelajaran ini tampak bahwa siswa kurang mendengarkan guru menyampaikan materi pelajaran, siswa masih kurang terlibat Tanya jawab, Siswa kurang menanyakan hal-hal yang belum di mengerti, Siswa kurang aktif bekerja sama dengan kelompoknya dalam menyelesaikan LKS, siswa kurang aktif dalam menyimpulkan materi yang telah di bahas.

Setelah melakukan analisis dan refleksi hasil belajar siswa pada siklus I, guru mata pelajaran dan peneliti mencoba melakukan perbaikan dalam proses belajar mengajar agar pada siklus selanjutnya siswa yang belum memenuhi ketuntasan belajar dapat meningkat seperti yang diharapkan.

$\begin{array}{rcr}\text { Pada } & \text { siklus II } \begin{array}{r}\text { guru } \\ \text { menekankan }\end{array} \text { kepada } & \text { siswa }\end{array}$ mendengarkan guru menyampaikan materi pelajaran, agar siswa terlibat Tanya jawab, agar siswa menanyakan hal-hal yang belum di mengerti, agar siswa aktif bekerja sama dengan kelompoknya dalam menyelesaikan LKS, agar siswa aktif dalam menyimpulkan materi yang telah di bahas, karena siswa yang mendapat nilai tertinggi akan mendapatkan penghargaan atau hadiah dari guru. Berdasarkan hasil tes belajar siswa pada akhir siklus, terlihat bahwa hasil belajar siswa memperoleh nilai minimum 52,2nilai maksimum 95,7; nilai rata-rata hasil belajar siswa sebesar 78\%.Terdapat 19 siswa yang memperoleh nilai $\geq 68$ atau ketuntasan belajar secara klasikal sebesar 82,6\% sedangkan jumlah siswa yang hasil belajarnya di bawah KKM atau yang memperoleh nilai $<68$ sebanyak 4 orang atau $17,4 \%$ yang belum tuntas.Dari hasil tersebut menunjukan peningkatan hasil belajar yang signifikan dari siklus I ke siklus II, walaupun masih ada 4 siswa yang belum mencapai ketuntasan belajar.

Pada siklus II target ketuntasan hasil belajar siswa telah tercapai yaitu $82,6 \%$ siswa telah tuntas dalam hasil belajarnya. Hal ini peneliti dianggap telah berhasil mencapai targetnya. Dalam penelitian ini keberhasilan siswa dalam tes hasil belajar siklus II memberikan gambaran bahwa penerapan Model Pembelajaran Koopertif tipe Talking Stickpada materi pokok keragaman bentuk muka bumi mampu meningkatkan hasil belajar siswa.

Dengan demikian jawaban atas permasalahan penelitian telah ditemukan yaitu pembelajaran dengan menerapkan Model Pembelajaran Kooperatif tipeTalking Stickberhasil meningkatkan hasil belajar IPS siswa kelas VII SMP Negeri 2Towea khususnya pada materi pokok keragaman bentuk muka bumi.

\section{PENUTUP}

Berdasarkan rumusan masalah dan hasil analisis data dalam penelitian ini dapat ditarik beberapa kesimpulan sebagai berikut:

1. Gambaran aktivitas belajar siswa dengan menerapkan Model Pembelajaran Kooperatif tipe Talking Stick materi pokok keragaman bentuk muka bumi pada setiap siklus cenderung meningkat. Hal ini ditunjukan dengan skor rata-rata pada setiap siklus, dimana pada siklus I skor rata-rata aktivitas belajar siswa adalah 2,5 yang termasuk kategori Cukup meningkat padasiklus II menjadi 3,2 yang termasuk pada kategori Baik.

2. Gambaran aktivitas mengajar guru dengan menerapkan Model Pembelajaran Kooperatif tipe Talking Stick pada materi pokok keragaman bentuk muka bumi pada setiap siklus cenderung meningkat. Hal ini ditunjukan dengan skorrata-rata pada setiap siklus, dimana pada siklus I skor rata-rata aktivitas mengajar guru adalah 2,9yang termasuk kategori Cukup dan 
Jurnal Penelitian Pendidikan Geografi Volume 3 No. 4 Oktober 2018

meningkat pada siklus II menjadi3,1yang berkategori Baik.

3. Peningkatan hasil belajar IPS siswa kelas VII SMP Negeri Satap 2 Towea dapat meningkat dengan menerapkan Model Pembelajaran Kooperatif tipe Talking Stick pada materi pokok keragaman bentuk muka bumi. Dimana pada siklus I diperoleh nilai terendah 43,5 , nilai tertinggi 95,7 , nilai rata-rata $71 \%$ dan ketuntasan hasil belajar sebesar $60,9 \%$ yaitu dari 23 siswa terdapat 14 siswa yang memperoleh nilai $\geq 68$ (KKM). Pada siklus II diperoleh nilai terendah 52,2 , nilai tertinggi 95,7 , nilai rata-rata 78 dan ketuntasan hasil belajar $82,6 \%$ yaitu dari 23 siswa terdapat 19 siswa yang memperoleh nilai $\geq 68$ (KKM). Dengan demikian penelitian ini di katakan berhasil dengan penerapan Model Pembelajaran Kooperatif tipe Talking Stick .

Berdasarkan kesimpulan diatas, maka penelitimengemukakan beberapa saran berikut:

1. Bagi sekolah, khususnya SMP Negeri Satap 2 Towea dapat mencoba untuk menerapkan Model Pembelajaran Kooperatif tipe Talking Stick pada pembelajaran IPS untuk mengatasi banyaknya siswa yang pasif serta untuk meningkatkan hasil belajar siswa pada mata pelajaran IPS.

2. Bagi peneliti selanjutnya, terus mencari informasi dan mempelajari Model Pembelajaran Kooperatif tipe Talking Stick sebelum melakukan Penelitian Tindakan Kelas (PTK) khususnya pada tahap-tahap Model Pembelajaran Kooperatif tipe Talking Sticksehingga diharapkan hasil yang diperoleh lebih baik lagi dari peneliti sebelumnya.

3. Dalam penelitian ini peneliti menyadari masih banyak kekurangan-kekurangan baik dalam hal perencanaan penelitian, pelaksanaan penelitian dan penganalisisan data hasil penelitian sampai dengan penarikan kesimpulan. Karena peneliti juga hanyalah manusia biasa yang tidak sempurna dan tidak pernah luput dari kesalahan.

\section{DAFTAR PUSTAKA}

Arikunto S. 2006. Penelitian Tindakan Kelas. Jakarta: Bumi Aksara.

Ibrahim, 2002.Pembelajaran Koperatif.Surabaya :Universitas Negeri Surabaya.

Iskandar, 2012.Penelitian Tindakan Kelas. Jakarta: Referensi.

Jumiati. 2015. Penggunaan Model Pembelajaran KooperatifTipe Talking Stick Untuk Meningkatkan Hasil Belajar Geografi Siswa Kelas $X_{3} S M A$ Negeri 10Kendari. Kendari: Universitas Haluoleo.

Robani dan Ahmadi. 1995. Pengelola Pengajaran. Jakarta: Rineka Cipta.

Saputra. 2005. Pembelajaran Kooperatif Untuk Meningkatkan Keterampilan Anak TK. Jakarta: Departemen Pendidikan Nasional Direktorat Jenderal Pendidikan Tinggi.

Sudjana, 2002.Metode Statistika.Bandung: Tarsito.

Sudjana Nana. 2010. Penilaian Hasil Proses Belajar Mengajar.Bandung: PT Remaja Rosdakarya.

Suparno, P. 2008. Riset Tindakan untuk Pendidik. Jakarta: PT. Gramedia Widiasarana.

Susetyo, B. 2008. Statistka Untuk Analisis Data Penelitian. Bandung: Refika Ditama.

Usman dan Setiawati, 2001.Statistika. Bandung: Remaja Rosdakarya. 
Jurnal Penelitian Pendidikan Geografi Volume 3 No. 4 Oktober 2018

Wardani, I. G. A. K. 2004.Penelitian

Tindakan Kelas. Jakarta:

Universitas Terbuka.

Winkel, W. S. 1988. Psikologi Pengajaran.

Surabaya: Usaha Remaja. 